\title{
Studying Past Landscapes: Lived, Reconstructed and Animated
}

\author{
Krista Karro \\ Tallinn University \\ Estonian Institute of Humanities \\ Centre for Landscape and Culture \\ Tallinn, Estonia \\ email: krista.karro@tlu.ee \\ Marika Mägi \\ Tallinn University \\ Institute of History \\ Department of Archaeology \\ Tallinn, Estonia \\ email: marika.magi@mail.ee

\section{Hannes Palang} \\ Tallinn University \\ Estonian Institute of Humanities \\ Centre for Landscape and Culture \\ Tallinn, Estonia \\ email: palang@tlu.ee
}

Accepted: 13 February 2014

Published: 4 March 2014

\begin{abstract}
This article deals with the contemporary situation in the study of past landscapes. An overview of past landscapes' nature is given, then different categories of research approaches are described and explained, and in the main part of the article diverse methodologies of past landscape research are explained and exemplified. The approaches mentioned in the article are settlement archaeology and field-system analysis, path dependency, phenomenology and landscape biography. Those approaches are the most common and modern ways of studying past landscapes, but the authors will argue that the best results will be gained combining different aspects of those approaches.
\end{abstract}

Keywords: past landscapes, landscape biography, path dependency, phenomenology, settlement archaeology

This review is licensed under a Creative Commons Attribution-Non-Commercial 3.0 Germany License. http://creativecommons .org/licenses/by-nc/3.0/de/ 


\section{Imprint / Terms of Use}

Living Reviews in Landscape Research is a peer reviewed open access journal published by the Leibniz Centre for Agricultural Landscape Research (ZALF), Eberswalder Straße 84, 15374 Müncheberg, Germany. ISSN 1863-7329.

This review is licensed under a Creative Commons Attribution-Non-Commercial 3.0 Germany License: http://creativecommons.org/licenses/by-nc/3.0/de/. Figures that have been previously published elsewhere may not be reproduced without consent of the original copyright holders.

Because a Living Reviews article can evolve over time, we recommend to cite the article as follows:

Krista Karro, Marika Mägi and Hannes Palang, "Studying Past Landscapes: Lived, Reconstructed and Animated", Living Rev. Landscape Res., 8, (2014), 1. URL (accessed < date>): http://www.livingreviews.org/lrlr-2014-1

The date given as $<$ date $>$ then uniquely identifies the version of the article you are referring to.

\section{Article Revisions}

Living Reviews supports two ways of keeping its articles up-to-date:

Fast-track revision. A fast-track revision provides the author with the opportunity to add short notices of current research results, trends and developments, or important publications to the article. A fast-track revision is refereed by the responsible subject editor. If an article has undergone a fast-track revision, a summary of changes will be listed here.

Major update. A major update will include substantial changes and additions and is subject to full external refereeing. It is published with a new publication number.

For detailed documentation of an article's evolution, please refer to the history document of the article's online version at http://www.livingreviews.org/lrlr-2014-1. 


\section{Contents}

1 Introduction: Landscapes of the past 5

2 Categorizing methodologies $\quad 6$

3 Deconstructing landscapes: Historical land-use research and settlement archaeology

4 Changing landscapes: path dependency $\quad 9$

5 The frog perspective: phenomenological method 10

6 Reconstruction, animation and absence: Landscape biography 12

$\begin{array}{lll}7 & \text { Conclusion } & 13\end{array}$

$\begin{array}{ll}\text { References } & 14\end{array}$ 



\section{Introduction: Landscapes of the past}

Past is a collective ghost - always here but never fully recognizable.

(Lowenthal, 1985, 14)

In 2010 an interesting find was uncovered in Paris. A lady left her apartment during the World War II and never returned. She kept paying the bills for it, so the flat stood untouched for 70 years, until it was opened again in 2010 (Samuel, 2010). When the first eyes were laid on it in 2010 , it was probably like a snapshot from the middle of the 20th century. It was a past landscape - not reconstructed, but saved - a supposedly real past landscape. This is certainly something that most landscape archaeologists and historians would like to uncover instead of having to fill in the blanks - a museum of an actual lived landscape. In this case most researchers probably agree that this find includes a great deal of reality. Past landscape researchers should strive for reality, but it is also important to understand that not only snapshots are sought but dynamic changing landscapes, and this is what the article is going to discuss.

According to the European Landscape Convention (ELC) landscapes are areas, as perceived by people, which character is the result of the action and interaction of natural and human factors. However, there are other circumstances that should be noted when talking about landscapes. Landscapes are constantly being transformed by the people living in them, thus, landscapes are never frozen entities but lively and dynamic. Landscapes can be considered as lived spaces or lebensraum, however, Tim Ingold has used the term meshwork to replace the German term, which has a more nuanced meaning than the English space (see also Lefebvre, 1991; Simonsen, 2005, 7). When the ELC suggests that landscapes are more like the occupation of worlds already built, then for this article landscapes are the very process of inhabiting the Earth (Ingold, 2009, 30-34).

As we are constantly living our contemporary landscapes, it is important to realize that the same happened also in the past - the inhabitants created their world by transforming and retransforming the environment around them (see, e.g., Gosden and Lock, 1998) - their landscapes were animated, and this is why past landscape researchers should also try and find that long gone life underneath layers of later activity and tie this into a coherent unity (see also Antrop, 2005).

As this article is dealing with past landscapes, let the term be divided into two - past and landscapes. First, let us discuss the latter term. Landscape is a human geographical notion that has numerous definitions, let some of the most famous landscape researchers be cited below:

"Landscape is a social and cultural product, a way of seeing projected onto the land and having its own techniques and compositional forms; a restrictive way of seeing that diminishes alternative modes of experiencing our relations with nature." (Cosgrove, 1984, 1, 269)

"Landscape is not merely an aesthetic background to life, rather it is a setting that both expresses and conditions cultural attitudes and activities, and significant modifications to landscapes are not possible without major changes in social attitudes." (Relph, 1976, 122)

"Environment changes into landscape in the eyes of the beholder who constructs landscape from the material environment." (Fairclough, 2008, 409)

But, landscape can also be understood as a group of places connected by roads, paths and stories (Tilley, 1994), whereas lives are not lead inside places but through, around, to and from them, from and to places elsewhere (Ingold, 2000, 229). Also, landscape has been defined as a work in progress (ibid., 199). Numerous books and articles have been written on different meanings of landscape 
and how this notion has developed (e.g., Johnson, 2007; Widgren, 2012), but in no condition it is possible to neglect that landscape has a temporal dimension and it is closely connected with anthropogenic activity (Ingold, 2000). Or, as Sylwan (2011, 11) has put it - we inaugurated our own age as an independent ecological factor. As a remark it is also interesting to note that already the old German meaning of the word lantscap had the additional anthropogenic meaning to it it meant the territory of land, but also the community connected to it and its traditions (Olwig, 2002; Elerie and Spek, 2010).

From the previous discussion it is possible to conclude that landscape really does no exist out of human mind (see, e.g., Vedru, 2002) nor out of time. Thus, this brings us to the former and the key part of the phrase mentioned at the beginning of this section: past, or in other words, temporality. When archaeological or historical landscapes are concerned, always the time that has already passed is being studied, and this is what makes this research object difficult. Landscape itself is formed by continual succession of events (Zarina, 2013,6), that can be set in a period of time. Those events usually have a causal or path dependent connection with each other, and the latterly mentioned approach can be one of the ways to look back in time, and it will be explained below.

The term reconstruction is mostly used when past landscape research is concerned. One possible definition to the word is re-creation on the basis of available data, ${ }^{1}$ which conveys well the essence of the word. Herewith, study of past landscapes is always re-creating the landscape of a certain period and place out of the available evidence. The word create definitely refers to an imaginative aspect. Thus, it can be claimed that the reconstructions of past landscapes are imagined, and may or may not be real. Unfortunately, it is impossible to say how much reality those reconstructions actually include, because treating evidence and the use of different theories and methodologies affect the result (e.g., the difference between retrospective and reconstructive method: Widgren, 2006).

The notion of landscape is rooted in different disciplines, including archaeology, history, geography, anthropology, and several natural sciences. Therefore, to study landscapes, inter- and trans-disciplinary research must be conducted for the best result, and this article will follow the most important contemporary directions in past landscape research, including settlement archaeology, phenomenological landscape archaeology, landscape biography and path dependency. In other words, ways to reconstruct an animated past landscape will be sought in the next pages.

\section{Categorizing methodologies}

There are multiple ways to study past landscapes, and as the first larger-scale division those approaches can be entitled the eagle and the frog perspective.

Those metaphoric titles present the perspective of the observer. The eagle flies high above the landscape and sees the large-scale patterns but lacks the closer perception. This absence can be filled in by the frog that moves close to the ground, sees and perceives the surrounding landscape - the high and the low, the obstacles and the passages. When the eagle flies, a water body is not an obstacle, but for the frog, who walks on the ground, the water body needs passing through or going around, and this is why those two different methodologies can be used in studying different aspects of landscapes, and in the best case they, of course, support each other and produce a more wholly picture of the landscape. In other words, the eagle's perspective sets the stage and the frog's perspective helps to (re)create the dynamics of the landscape, that is for these authors the key aim in past landscape research.

1 "Reconstruct", Dictionary.com, URL (accessed 9 April 2013): http://dictionary.reference.com/browse/ reconstruct.

Living Reviews in Landscape Research

http://www. livingreviews.org/lrlr-2014-1 
From the eagle perspective the most common ways of studying past landscapes are settlement history and archaeology. In those fields settlement patterns are studied very thoroughly, using all the available information. Key tools to these approaches are historical maps that help researchers to analyze changes in settlement patterns, but also in communications joining different settlement units. Changes in different aspects of people's lives - economical, political, religious - also cause transformations in settlement patterns, and drawing maps of settlement patterns of different periods is usually the main goal of these approaches.

When settlement historical and archaeological approaches focus on the result of a transformation, path dependency concentrates on the reasons why changes have taken place. So, in a way, path dependent approach fills in the gaps that are left by the latter two mentioned approaches. Path dependency is mostly used in historical geography, but quite the same kind of approach can also be found in some archaeological works, although it has not been defined so. This approach can be considered as a means of social history and archaeology, but it also focuses on the large-scale changes and tries to see uniform transformations that have taken place in different areas.

When more individualistic approaches are concerned, landscape phenomenology is certainly a way of seeing the world from the frog perspective. It focuses on what people would see from a certain point in the landscape and how they would use what they see in building their landscape. Considering that past landscapes are very often fragmented, meaning that not all has preserved and the environment has also changed, it is questionable whether this approach alone would help to reconstruct a past landscape, but it definitely gives information that other approaches do not.

In the next four sections it is shown how landscapes are de- and reconstructed in historical geography and settlement archaeology, then are made dynamic again by the help of path dependency and phenomenological archaeology, and how those methodologies should help to build up a landscape biography.

\section{Deconstructing landscapes: Historical land-use research and settlement archaeology}

The methodologies discussed in this section are the more traditional ways in past landscape research. In works following them the regional division of study areas and land use pattern according to regions seem to be the main two research objectives. Those aims are usually approached 'top down' or 'bottom up' (Rippon, 2012, 15), meaning that either study questions or a research area is picked first.

First, let us observe the development of the term historic landscapes. It was first taken into use in the UK in 1993 to advise planners and countryside managers on the historical depths present in the modern landscape (Rippon and Turner, 1993; Rippon, 2012, 54). A little later, English Heritage developed it into a methodology called Historic Landscape Assessment (HLA), which has been carried out regionally in the UK (Aldred and Fairclough, 2003; Rippon, 2004).

This is where the concept of region becomes significant. Works on historic landscapes are mostly about a certain region, whether it is a nested study emanating from a study question (see, e.g., Rippon, 2004, 2006; van Beek and Louwen, 2012) or a complete study of a region (e.g., Lang, 1996; Spek, 2004; van Beek, 2011). The concept region comes from the French term pays, which means regions with a distinctive character caused by different natural and social conditions (Muir, 1999; Rippon, 2012). There are usually frontiers between regions that mark areas of different religions and ideologies, but borders can also be between humans and nature (Corbin, 1994).

Regional division originates from nature geography, where geographical areas of distinctive geology and vegetation were divided into landscape regions (the German School: e.g., Brückner, 1895; Penck, 1909, 1924; for Estonia see, e.g., Granö, 1922; Kurs, 1995; Arold, 2005), but as the term landscape widened with the development of the so-called New Geography, social, political, religious and other kind of human conditions also became distinctive aspects of regions. 
Regional division of an area may be entitled a spatial layer of landscape, which can be either geographical or geological, but also cultural (Karro, 2010a, 185). The cultural way of spatial layering comprises dividing the landscape on the basis of land-use systems. An interesting study based on this was written by Rippon (2012), where he tried to understand why the land-use was different on each side of the Blackdown hills in England. In Estonia this kind of approach has been used a few times since 1990s. Lang (1996) has analyzed the Iron Age landscape of northern Estonia based on settlement patterns, using the method of dividing the area into settlement districts, settlement areas and settlement units, the first being a large area that includes the second and the third. However, he has used the spatial analysis method of Thiessen's polygons (Binford, 1977) to form settlement units, but the result is not always adequate with Estonian archaeological material. Often, when a settlement site location is unknown, he has taken the location of a burial site as a starting point for a polygon. This has created a situation where burial sites are in the center of settlement units, but actually it is quite definite that burial sites were erected in liminal areas whereas villages or farms were in the centers of settlement units. The latter is also stated in his definition of a settlement unit, but the results of the polygons tell a different story. Thus, that kind of modeling is not possible to use in Estonia, because there is not enough archaeological material. (Mägi, 2002) has accomplished an analogical aim with the landscapes of the island Saaremaa, however, she has used the terminology of areas and sub-areas created with a different methodology. Namely, her areas and sub-areas follow natural borders and the spread of agricultural land. However, to show that this kind of perspective is not new in Estonia, a work from the 19th century should also be mentioned. Grewingk (1882) compiled a work about a Stone Age settlement site considering geological and geographical conditions. From the field of settlement history Paul Johansen should be mentioned, who has written about the importance of settlement history already in the 1930s (see, e.g., Johansen, 2005). He emphasized cartography, archaeology, and place-names as the vital tools in studying settlement history, and has called this discipline a significant national task (Johansen, 2005, 13). Among other things, he has published the Liber Census Daniae, which is the record book of land-use from the 13th century northern Estonia, compiled by the order of the Danish king who at that time owned this area (Johansen, 1933). This is the first mentioning of many villages in North-Estonia, thus Johansen's publication is quoted a lot by historians and archaeologists who study the past of Estonia. Johansen relied much on written sources, and another such example can be found in Latvia - Urtāns (1998) has tried to locate the central castle of the Metsepole regions based on the Chronicle of Henry of Livonia.

Dutch past landscape research is very similar to settlement archaeology adopted in the UK and Estonia, but it is more focused on land-use systems rather than settlement structures. This probably comes from the fact that the Netherlands have always had many people and little arable land, and water-management has always played a great role in land-use systems as a whole. The doctoral thesis of Spek (2004) is a very good example of a research where the land-use patterns of different periods have been analyzed in the county of Drenthe in northern Netherlands. However, there are other kind of great examples of such from the Netherlands that deal more with the prehistoric and roman past of the country (e.g., van Beek, 2011).

Those two mentioned works show the importance of nature geography in human geography. In other words, it is impossible to understand human behavior without knowing natural conditions they lived in. The present author's undergraduate thesis about a landscape region in eastern Estonia also followed this idea (Karro, 2010b). Those works are the ones that combine natural and human geography, but there is also a direction called geo-archaeology, which is very severely biased towards natural sciences, dealing less with human behavior (e.g., Monaghan and Lovis, 2005).

To conclude this section, it must be said that historical land-use research and settlement archaeology contribute a lot from natural sciences like geology, geo-ecology, palynology, paleo-botany, etc, and the aim of many of the works is future-oriented - to inform landscape planners that they must consider the relict landscapes of the area in future planning (Rippon, 2012, 54-55). 


\section{Changing landscapes: path dependency}

When the stage has been set, it is time to animate it. The best way to do that is to rely on the temporality of landscape. This is one of the aspects touched by many landscape researchers. Vedru $(2009,22)$ has written that the layers of different time periods are intertwined in the landscape and create a unique whole. Palang (2001) in his definition of landscape also emphasizes the importance of temporality, for it is one of the components of landscape. One of the present authors has found in her earlier article that time is the dimension that ties together all the layers of landscape (Karro, 2010a, 184).

Deriving from the idea of temporality, it is possible to say that landscape is a continuity of succession formed by multiple sequences of events. Those events have causal effects on one another, and sometimes small-scale events can cause powerful responses and move systems in a new direction (Zarina, 2013, 4-6). This is how the path dependent approach can be explained in the context of past landscape studies.

Path dependent sequences of events are sequences in which the outcome is not that important as the events that trigger changes or so-called breaking points (Mahoney, 2000; Zaringa, 2013). So, the key concept here is change, on which past landscape studies should actually focus on instead of objects, like settlements, fields, etc. (Muir, 2002).

Change in the landscape can and has been approached from different aspects. It is possible to study the changing character of a single object, or a wider landscape that has been, for example, influenced by a certain political system. Next some examples of both will be made.

Archaeologists very often speak of monuments. When heritage protection is concerned, such approach is sensible, because it is much easier to protect one monument instead of a landscape. However, to find that protection-worthy significance in a monument, its life-story has to be compiled, and it very often is path dependent. In other words, such a life-story can be called the analysis of monument re-use, which was very popular in the British archaeology at the end of the 1990s and the beginning of 2000s (e.g., Holtorf, 1998; Bradley, 1998, 2000). Although such re-use analyses deal more with single monuments than with whole landscapes, it is an interesting way in past landscape research and is definitely worth mentioning in the context of this article. When dealing with change in wider landscapes, it is crucial to find events in a landscape's life that modify it. When whole landscapes are concerned, political and ideological, also religious changes transform them. Estonia with its Soviet past is, of course, a very good example for that, and Palang (2010) has analyzed the landscape before and after the Soviet era. When prehistory is concerned, e.g., Mägi (2006, 2007) has studied Estonian burial customs and tried to find ideological and religious reasons why collective burial traditions suddenly became individual in the 7 th century island of Saaremaa. To make an example out of Estonia, e.g., Spek (2004) has argued that transformations in social and political landscape change land-use systems and therefore the physical landscape. Such transformations have also been researched by, e.g., Mägi (2008, 2013) - she is convinced that changes in the social and ideological system are reflected in the establishment and localization of prehistoric harbors.

All in all, those examples show that past landscape research is abandoning single objects and starting to focus much more on change instead. After all, when archaeology is concerned, the analysis of a single monument or an artefact should be a tool, not so much an aim. An aim should, instead, be a perception of an animated landscape with its breaking points and physical results in the terrain and the social and political space. 


\section{The frog perspective: phenomenological method}

The last direction of past landscape research that is described and discussed in this article is phenomenology. Although it was the most popular in the 1990s, some attempts on using it are still made. It has been argued against in many works (e.g., Brück, 2005; Fleming, 2005; Barrett and Ko, 2009), however, the author of this article believes that the philosophy of historical phenomenology can help researchers to have an insight into the past time.

Phenomenology means first and foremost a method, which was created by members of a philosophical school: Edmund Husserl, Martin Heidegger, Jean-Paul Sartre and Maurice Merleau-Ponty (Viik, 2009). In the 1990s, this methodology was adopted in archaeology - every archaeologist who has taken interest in phenomenology is probably acquainted with A Phenomenology of Landscape by Tilley (1994) or The Hermeneutics of Megalithic Space by Thomas (1993). Some of the articles and books mentioned earlier in this article partly depict the phenomenological method (Gosden and Lock, 1998; Bradley, 2000), however, it is clear that by phenomenology only it is not possible to reconstruct a landscape, but it certainly takes closer to the final aim of animatedness.

Basically, phenomenological method includes perceiving the minds of the past people, who inhabited a landscape, in order to find out how they could have interpreted it. However, the perceiving is the problem that has given a reason to argument against this method. Thus, the question is if it is possible to understand what the people, who lived a thousand and more years ago, actually thought, and how it can be achieved. Historical phenomenology in connection with theories of corporeality might help closer to understanding the past world as the contemporary people did it.

Namely, Carr (2012) has argued that memory and experience are the keys to reach the past. Past, present and future form a horizon where present is highlighted, but it is also given meanings by the past and the future. A sole event cannot be experienced, but the field of past-present-future is experienced and perceived along with this event - this way the past is closely connected to the experience of the present.

This theory supports the theory of Gumbrecht (2013) of chronotopes or how the past is perceived by the present people (see also Bakhtin, 1981). Namely, he claims that the chronotope changed after the World War II and now it is possible to say that the present is inundated by pastness and the past is latent - something that cannot quite be left behind but is always with us in the present. This idea can be coincided with the idea of Torop (2012) that every era has its own past, which is created by academics but also artists, writers, composers, etc. All of those pasts must integrate and thus form a collective cultural identity and common understanding of history.

Furthermore, phenomenological method is closely connected to bodily experience. People are corporeal beings, they relate to nature and past, range in scale of corporeal attitudes and gestures to overall social practice. Each living body is space and has its space, meaning that it produces itself in space at the same time as it produces that space. External space is perceived through orientation and demarcation, the former of which replicates the body by projecting pairs of determinants, such as left and right, into the world, and the latter of which adds directions which are not only guidance to the world but also make it meaningful (Simonsen, 2005, 2-4).

People have always been and are corporeal beings and their perception of the world is somewhat similar in all ages. However, the pastness in every epoch is different, which really does make it difficult to understand the interpretation of the people who lived some thousand years ago. An answer to this problem might be approaching from micro-level and trying to understand the pastness of the people who inhabited the area of interest later. Understanding may be possible through, i.e., folklore about the same natural object that has been there earlier and later. To make an example, let us talk about a lake that has been used for thousands of years for different purposes. The period of interest is prehistory, but there are no more sources than scarce archaeological finds from that era. Then it is possible to turn to a later community who had a similar economical base 
than the prehistoric society, and who also therefore used the lake. The later community, however, has much folklore about the lake, which is a good source to understand their perception of this landscape, and it is very possible that the prehistoric people also had similar perceptions than the later community, because their ways of using the lake were similar, and this fact is evident in archaeological material (Karro, 2013b).

Furthermore, it is possible to detect the past in the present physical landscape and read it out from there. This idea is also supported by the article of Vedru (2009) on layers of landscape, where she argues that landscape is temporally layered and it is still possible to see the layers of the past in the contemporary landscape (Figure 1; see also the conception of palimpsest Vervloet, 1984). However, this assumes that landscapes, as well as life-stories of people, are narratives, and narratives of landscapes are formed of individual and collective life-stories of the inhabitants (Duncan, 1990; Karro, 2013a). Thus, to use this kind of methodological approach, it is necessary to connect the narratives of the landscape and the people who could function as mediators to the more far-away past.

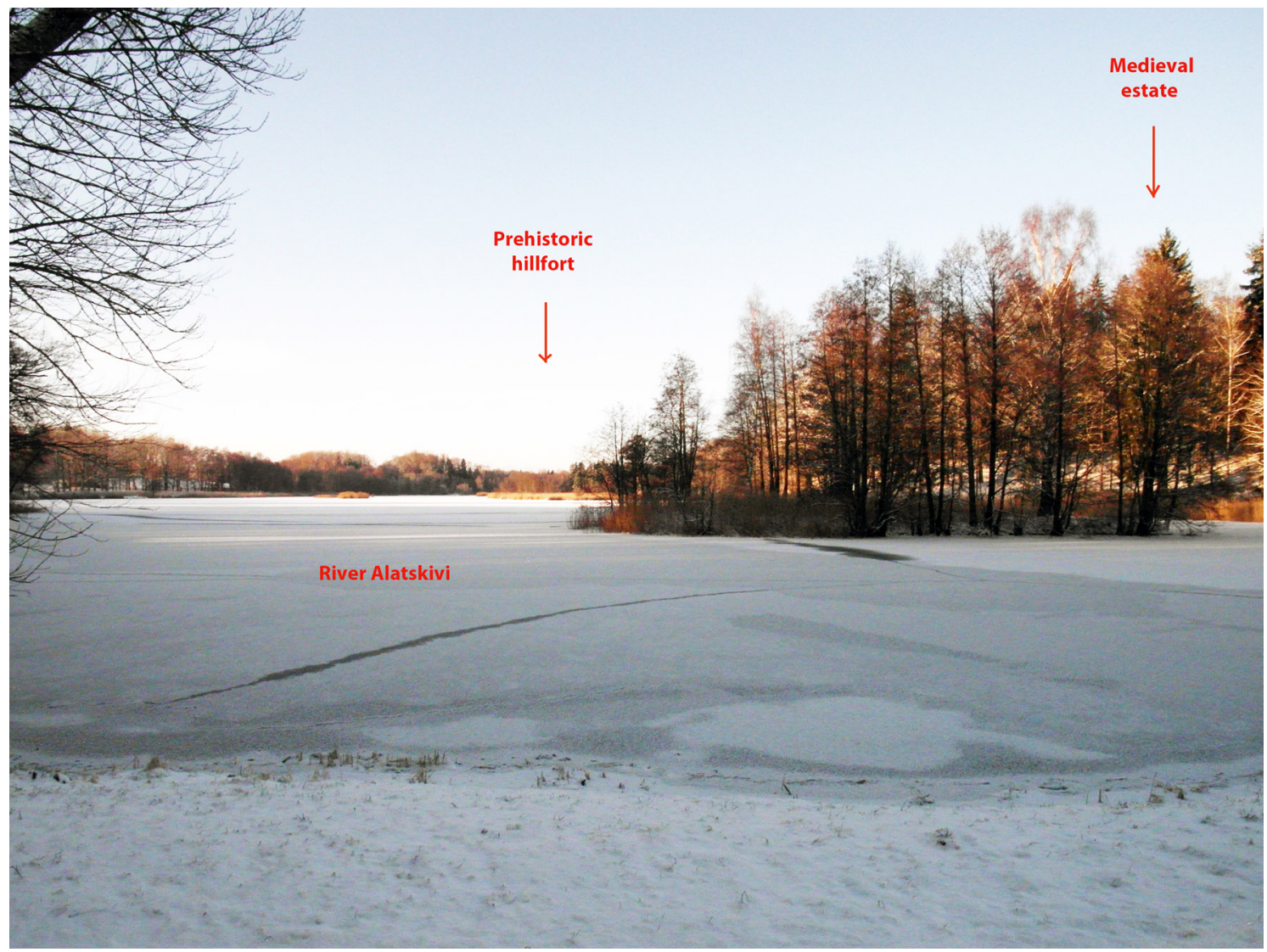

Figure 1: Temporal dimensions in the landscape of Alatskivi, Kodavere parish, eastern Estonia. There is a prehistoric hillfort dating to $150 \mathrm{BC}-1100 \mathrm{AD}$ on the southern shore of the ancient River Alatskivi, and the Medieval (from ca the 13th century onwards) estate / centre of the area is located on the northern shore. The photograph has been taken from the site of the early modern estate / manor (first mentioned in 1601). The river has been widened to design the manor park also in the 17th century, and is now a combination of two lakes. 
Human perception and perspective is central in phenomenological method, and in combination with understanding that landscape is human creation and lies, first and foremost, in human mind, it is possible to analyze why the physical landscape was designed the way it was. The human-centered perspective gives landscapes the livelihood emphasized above.

The human-centeredness is very well represented in Vedru's works, e.g., her Ph.D. thesis Archaeological landscapes of North-Estonia (Vedru, 2010), where she discusses, for example, sights from one archaeological object to another. This dwells on the concept that in erecting a certain object, for example, a stone grave, it was important to see another site from that object, be that a boulder or a lake, because those sites together formed a religious or ideological landscape. Different heights of landforms and sights from them were also probably important to the past people (Vedru, 2013). All in all, in creating their landscape, people engaged their natural surroundings into their landscape which they created and re-created by living there, and phenomenological method strives for finding out why, and what they exactly used.

The connection between natural or human-made objects by roads and paths has been already discussed by British archaeologists in the 1990s and the first decade of the 2000s (e.g., Tilley, 1994, 2004, but also Bradley, 2000), and Vedru's works are a kind of revival of this methodology in Estonia.

To conclude this section, it can be said that phenomenology as an approach in the research of past landscapes has been and is criticized a lot, but it keeps coming back. Possibly, the reason is that it is an alternative perspective and methodology to harder sciences like artefact research, geo-archaeology, written source analysis, etc. In a good past landscape study it is necessary to have another approach as well, because it gives artefacts to people who use them in their everyday life, and face and feelings to those people whose story the landscapes are actually trying to narrate. In other words, phenomenological approach helps to animate landscapes, or to turn back to the statement by Gosden and Lock (1998) statement, helps to restore the heat and urgency in them.

\section{Reconstruction, animation and absence: Landscape bio- graphy}

One of the modern directions in past landscape research is compiling landscape biographies. It originates mostly from the UK, but there are some examples from other countries, too (e.g., Kolen and Witte, 2006). In fact, many works that analyze a landscape in several time periods can be defined as landscape biographies, and many of those have been mentioned already above (e.g., Spek, 2004; Rippon, 2012). Another work worth mentioning is Avebury: the biography of a Landscape by Pollard and Reynolds (2002), where the authors discuss an English landscape through time, and by using different methods manage to create quite a lively picture of this landscape and its changes. This book represents a past landscape analysis from the viewpoints of settlement and social archaeology, human and natural geography and geology. The phenomenological side is not well represented in this book, and this is, probably, why it is lacking the livelihood in this reconstruction.

When past landscapes are concerned, there is always something absent from them. And what is absent can be interpreted in several ways. For example, when there is a stone grave in the landscape of the Bronze Age, but no actual cultural layer of a settlement site, it is only possible to assume where the people who used the grave lived and what kind of rituals were conducted on the grave. The further back in time we go, the more is absent, and has to be filled in with the researcher's interpretation and knowledge, which is also an interesting subject of research (see, e.g., Bender et al., 2007). Therefore, landscape can also be defined as a series of tensions between the observer and the observed, interior and exterior, the invisible and the visible set in motion (Wylie, 2007, 2009). And this is why landscape reconstructions are always subjective, but the subjectivity 
itself actually animates them.

A life-story of a person is also considered a biography, but this narrative is full of emotions, alive and dynamic. A landscape biography should also include this dynamics, only then it becomes truly worthy of representing a past landscape.

\section{Conclusion}

Now it is time to turn back to the example made in the introduction - the room in Paris that was closed for 70 years. It is a snapshot - a museum-like saved landscape. It is certainly not like going back in time on a time machine, which is probably the dream of many past landscape researchers, but an old withered photograph. Yes, it is probably quite authentic, for the room was untouched for all this time, but it lacks life, and this is what should be an aim of past landscape research.

Many directions of past landscape research have been discussed in this article: from the comprehensive perspective of settlement archaeology, research of historic land-use systems and path dependency to the more personal view of phenomenological archaeology. Landscape is a meshwork that includes different individual and collective life-stories and encompasses long periods of time. The reconstructions of past landscape should focus on transformations in social, ideological and religious spheres to see the reasons behind changes in physical landscape. Those transformations can be large-scale and impersonal, but may have been triggered by or compiled from individual lives of the members of societies. In other words, people matter, because landscape as such is formed in the human mind and does not exist out of it.

Nowadays researchers are trying to combine different methods to encompass longer time periods in different landscapes and to reach closer to past reality. Landscape biography is at the moment the most important methodology of looking back in time, and it is used in different countries in slightly variable ways (see, e.g., Roymans et al., 2010 in the Netherlands; Rippon, 2012 in the UK). Researchers are even trying to combine very different methods like GIS-modelling and phenomenology (e.g., Graves McEwan, 2012), the purpose of such attempts is to check the results of different methodologies in order to improve both methods. Interdisciplinarity is practically unavoidable in past landscape research at the time when the discussion between arts and sciences becomes more and more common in order to achieve the best results.

Let this article be finished with a thought of why past landscapes should be studied at all. As landscape is formed out of individual identities, it also works vice versa - without knowing where we come from or understanding what brought us to the present - or why - we cannot pronounce on the future (Sylwan, 2011, 10).

\section{Acknowledgements}

This research has been financed by the Estonian Research Agency (IUT 3-2 Culturescapes in transformation: towards an integrated theory of meaning making; IUT18-8 The Making of Livonia: Actors, Institutions and Networks in the Medieval and Early Modern Baltic Sea Region) and by the European Union through the European Regional Development Fund (Centre of Excellence in Cultural Theory), and research grand no 9027 of the Estonian Ministry of Education. 


\section{References}

Aldred, O. and Fairclough, G. (2003), "Historic Landscape Characterization: Taking Stock of the Method. The National HLC Method Review 2002", Taunton (English Heritage \& Somerset County Council). (Cited on page 7.)

Antrop, M. (2005), "Why landscapes of the past are important for the future?", Landscape and Urban Planning, 70(1-2): 21-34, [DOI]. (Cited on page 5.)

Arold, I. (2005), Eesti maastikud, Ph.D. thesis, Tartu Ülikooli kirjastus, Tartu. (Cited on page 7.)

Bakhtin, M.M. (1981), "Forms of time and of the chronotope in the novel", in The Dialogic Imagination: Four Essays, pp. 84-258, Austin (University of Texas Press). [Google Books]. (Cited on page 10.)

Barrett, J.C. and Ko, I. (2009), "A phenomenology of landscape: a crisis in British landscape archaeology?", Journal of Social Archaeology, 9: 275-294, [DOI]. (Cited on page 10.)

Bender, B., Hamilton, S. and Tilley, C. (2007), Stone Worlds: Narrative and Reflexivity in Landscape Archaeology, Walnut Creek, CA (Left Coast Press). [Google Books]. (Cited on page 12.)

Binford, L.R., ed. (1977), For Theory Building in Archaeology: Essays on Faunal Remains, Aquatic Resources, Spatial Analysis, and Systematic Modeling, New York; San Francisco; London (Academic Press). (Cited on page 8.)

Bradley, R. (1998), "Ruined buildings, ruined stones: Enclosures, tombs and natural places in the Neolithic of south-west England", World Archaeology, 30(1): 13-22, [DOI]. (Cited on page 9.)

Bradley, R. (2000), An Archaeology of Natural Places, London; New York (Routledge). (Cited on pages 9, 10, and 12.)

Brück, J. (2005), "Experiencing the past? The development of a phenomenological archaeology in British prehistory", Archaeological Dialogues, 12(1): 45-72, [DOI]. (Cited on page 10.)

Brückner, E. (1895), "Der Einfluß der Klimaschwankungen auf die Ernteerträge und Getreidepreise in Europa", Geographische Zeitschrift, 1: 39-51. (Cited on page 7.)

Carr, D. (2012), "Experience and history", in Zahavi, D., ed., Oxford Handbook of Contemporary Phenomenology, Oxford (Oxford University Press), [DOI]. (Cited on page 10.)

Corbin, A. (1994), The lure of the sea: The discovery of the seaside in the western world 1750-1840, Oxford (Blackwell Publishing). (Cited on page 7.)

Cosgrove, D.E. (1984), Social Formation and Symbolic Landscape, London (Croom Helm). [Google Books]. (Cited on page 5.)

Duncan, J.S. (1990), The city as text: the politics of landscape interpretation in the Kandyan kingdom, Cambridge Human Geography, Cambridge; New York (Cambridge University Press). [Google Books]. (Cited on page 11.)

Elerie, H. and Spek, T. (2010), "The cultural biography of landscape as a tool for action research in the Drentsche Aa National Landscape (Northern Netherlands)", in Bloemers, T., Kars, H., van der Valk, A. and Wijnen, M., eds., The Cultural Landscape 83 Heritage Paradox: Protection and Development of the Dutch Archaeological-Historical Landscape and its European Dimension, pp. 83-113, Amsterdam (Amsterdam University Press). [Google Books]. (Cited on page 6.)

Fairclough, G. (2008), "The long chain: Archaeology, historical landscape characterization and time depth in landscape", in Fairclough, G., Harrison, R., Jameson Jr, J.H. and Schofield, J., eds., The Heritage Reader, pp. 408-424, London; New York (Routledge). (Cited on page 5.) 
Fleming, A. (2005), "Megaliths and post-modernism: the case of Wales", Antiquity, 79(306): 921-932. (Cited on page 10.)

Gosden, C. and Lock, G. (1998), "Prehistoric histories", World Archaeology, 30(1): 2-12, [DOI]. (Cited on pages 5,10 , and 12.)

Granö, J.G. (1922), Eesti maastikulised üksused. 7 joonisega tekstis ja 3 kaardiga [Zusammenfassung: Die landschaftlichen Einheiten Estlands]. (Cited on page 7.)

Graves McEwan, D. (2012), "Qualitative Landscape Theories and Archaeological Predictive Modelling - A Journey Through No Man's Land?", Journal of Archaeological Method and Theory, 19: 526-547, [DOI]. (Cited on page 13.)

Grewingk, C. (1882), "Geologie und Archaeologie des Mergellagers von Kunda in Estland", Archiv für die Naturkunde Liv-, Ehst- und Kurlands, 2. Serie, IX: 1-72. Online version (accessed 25 February 2014): http://hdl.handle.net/10062/2070. (Cited on page 8.)

Gumbrecht, H.U. (2013), After 1945: Latency as Origin of the Present, Stanford, CA (Stanford University Press). [Google Books]. (Cited on page 10.)

Holtorf, C. J. (1998), "The life-histories of megaliths in Mecklenburg-Vorpommern (Germany)", World Archaeology, 30(1): 23-38, [DOI]. (Cited on page 9.)

Ingold, T. (2000), The Perception of the Environment: Essays on livelihood, dwelling and skill, London; New York (Routledge). [Google Books]. (Cited on pages 5 and 6.)

Ingold, T. (2009), "Against Space: Place, Movement, Knowledge", in Wynn Kirby, P., ed., Boundless Worlds: An Anthropological Approach to Movement, pp. 29-43,, New York; Oxford (Berghahn Books). [Google Books]. (Cited on page 5.)

Johansen, P. (1933), Die Estlandliste des Liber Census Daniae, Kopenhagen; Reval (Hagerup; Wassermann). (Cited on page 8.)

Johansen, P. (2005), Kaugete aegade sära, Tartu (Ilmamaa). (Cited on page 8.)

Johnson, M. (2007), Ideas of Landscape, Malden, MA; Oxford (Blackwell Publishing), [DOI]. (Cited on page 6.)

Karro, K. (2010a), "Kodavere Parish by Lake Peipus: The Development of the Cultural Landscape During the Iron Age", Archaeologia Baltica, 14: 184-196. (Cited on pages 8 and 9.)

Karro, K. (2010b), Kodavere - kihelkond Peipsi ä̈̈res: Kultuurmaastiku areng rauaajal, Master's thesis, Tallinn University, Tallinn, Estonia. (Cited on page 8.)

Karro, K. (2013a), "Ruptured Space and Time in Lahepera Burial Site in Eastern Estonia", Archaeologia Baltica, 19: 32-41. (Cited on page 11.)

Karro, K. (2013b), "Russian Old Believers as 'the people of the lake': a key towards understanding Iron Age lakeside landscape?", VI autumn conference of the Centre of Excellence in Cultural Theory. Embodiment, expressions, exits: transforming experience and cultural identity, 30.10-1.11. 2013 Tartu, Estonia, conference paper. (Cited on page 11.)

Kolen, J. and Witte, M. (2006), "A biographical approach to regions and its value for spatial planning", in Van der Knaap, W. and van der Valk, A., eds., Multiple Landscape: Merging Past and Present, Selected Papers from the Fifth International Workshop on Sustainable Land Use Planning, 7 -9 June 2004, pp. 125-147, Wageningen (Wageningen University Press). (Cited on page 12.)

Kurs, O. (1995), “Johannes Gabriel Granö Eestis", Akadeemia, 7(5): 1057-1077. (Cited on page 7.) 
Lang, V. (1996), Muistne Rävala, Vol. 2: Muistised, kronoloogia ja maaviljelusliku asustuse kujunemine Loode-Eestis, eriti Pirita jõe alamjooksu piirkonnas, Muinasaja Teadus / Research into Ancient Times, 4, Tallinn (Teaduste Akadeemia Kirjastus). [Prehistoric Rävala, Vol. 2: Antiquities, chronology and the establishment of farming settlement in North-West Estonia, with special reference to the area on the lower reaches of the Pirita River]. (Cited on pages 7 and 8.)

Lefebvre, H. (1991), The Production of Space, Oxford; Cambridge, MA (Blackwell). (Cited on page 5.)

Lowenthal, D. (1985), Past is a Foreign Country, Cambridge (Cambridge University Press). (Cited on page 5.)

Mägi, M. (2002), "Piirkonnad ja keskused: Asustus muinasaja lõpu ja varakeskaegsel Saaremaal arheoloogiliste, inimgeograafiliste ning ajalooliste allikate andmeil", in Lang, V., ed., Keskus - tagamaa ääreala: Uurimusi asustushierarhia ja võimukeskuste kujunemisest Eestis, Muinasaja Teadus / Research into Ancient Times, 11, pp. 169-232, Tallinn; Tartu (Teaduste Akadeemia Kirjastus). (Cited on page 8.)

Mägi, M. (2006), "Changing connections, changing society: Burial rites on Iron Age Saaremaa", in Bertašius, M., ed., Transformatio mundi: The transition from the Late Migration Period to the Early Viking Age in the East Baltic, Research Papers of the Department of Philosophy and Cultural Science, pp. 51-64, Kaunas (Kaunas University of Technology). (Cited on page 9.)

Mägi, M. (2007), "Collectivity Versus Individuality: The Warrior Ideology of Iron Age Burial Rites on Saaremaa", Archaeologia Baltica, 8: 263-278. (Cited on page 9.)

Mägi, M. (2008), "Facing the sea", in Lilja, S., ed., Leva vid Östersjöns kust. En antologi om naturförutsätningar och resursutnyttjande pa bada sidorav Östersjön ca 800-1800, pp. 82-103, Stockholm (Södertörns Högskola). (Cited on page 9.)

Mägi, M. (2013), "Bound for the Eastern Baltic: trade and centres 800-1200", in Barrett, J. and Gibbon, S., eds., Maritime Societies of the Viking and Medieval World, 31 May - 4 June 2008, Kirkwall, Orkney, McDonald Institute Monographs, Cambridge (University of Cambridge). (Cited on page 9.)

Mahoney, J. (2000), "Path dependence in historical sociology", Theory and Society, 29(4): 507-548, [DOI]. (Cited on page 9.)

Monaghan, W.G. and Lovis, W.A. (2005), Modeling Archaeological Site Burial in Southern Michigan: A Geoarchaeological Synthesis, Environmental Research, 1, East Lansing, MI (Michigan State University Press). (Cited on page 8.)

Muir, R. (1999), Approaches to Landscape, Basingstoke (Macmillan Press). (Cited on page 7.)

Muir, R. (2002), "Reading the landscape", Journal of the Scottish Association of Geography Teachers, 31: 6-20. (Cited on page 9.)

Olwig, K.R. (2002), Landscape, Nature, and the Body Politic: From Britain's Renaissance to America's New World, Madison, WI; London (Madison University Press). [Google Books]. (Cited on page 6.)

Palang, H. (2001), "Maastikest siin raamatus", in Palang, H. and Sooväli, H., eds., Maastik: loodus ja kultuur. Maastikukäsitlusi Eestis, Publicationes Instituti Geographici Universitatis Tartuensis, 91, pp. 8-10, Tartu (Tartu University Press). (Cited on page 9.)

Palang, H. (2010), "Time boundaries and landscape change: collective farms 1947-1994", European Countryside, 2(3): 169-181, [DOI]. (Cited on page 9.)

Penck, A. (1909), "The origin of the Alps", Bulletin of the American Geographical Society, 41: 65-71, [DOI]. (Cited on page 7.)

Penck, W. (1924), Die Morphologische Analyse: Ein Kapitel der Physikalischen Geologie, Geographische Abhandlungen, 2, Stuttgart (Engelhorn). (Cited on page 7.) 
Pollard, J. and Reynolds, A. (2002), Avebury: The biography of a landscape, Stroud (History Press). (Cited on page 12.)

Relph, E. (1976), Place and Placelessness, London (Pion). (Cited on page 5.)

Rippon, S. (2004), Historic Landscape Analysis: Deciphering the countryside, Practical Handbook, 16, York (CBA Publications). Online version (accessed 18 February 2014):

http://hdl.handle.net/10036/32872. (Cited on page 7.)

Rippon, S. (2006), "Landscape, Community and Colonization: The North Somerset Levels during the 1st to 2nd millennia AD", CBA Research Reports, 152, York (CBA Publications). (Cited on page 7.)

Rippon, S. (2012), Making Sense of an Historic Landscape, Oxford (Oxford University Press). [Google Books]. (Cited on pages 7, 8, 12, and 13.)

Rippon, S. and Turner, R. (1993), "The Gwent Levels Historic Landscape Study", Archaeology in the Severn Estuary, 4, UK (Severn Estuary Research Committee). (Cited on page 7.)

Roymans, N., Gerritsen, F., van der Heijden, C., Bosma, K. and Kolen, J. (2010), "Revitalizing history: moving from historical landscape reconstruction to heritage protection in the southern Netherlands", in Bloemers, T., Kars, H., van der Valk, A. and Wijnen, M., eds., The Cultural Landscape $\&$ Heritage Paradox: Protection and Development of the Dutch Archaeological-Historical Landscape and its European Dimension, pp. 387-406, Amsterdam (Amsterdam University Press). [Google Books]. (Cited on page 13.)

Samuel, H. (2010), "Parisian flat containing 2.1 million painting lay untouched for 70 years", online resource, The Telegraph. URL (accessed 9 April 2013):

http://www.telegraph.co.uk/news/worldnews/europe/france/8042281/

Parisian-flat-containing-2.1-million-painting-lay-untouched-for-70-years.html. (Cited on page 5.)

Simonsen, K. (2005), "Bodies, sensations, space and time: the contribution from Henri Lefebvre", Geografiska Annaler: Series B, Human Geography, 87: 1-14, [DOI]. (Cited on pages 5 and 10.)

Spek, T. (2004), Het Drentse esdorpenlandschap: Een historisch-geografische studie, Utrecht; Assen (Matrijs; Stichting het Drentse). PhD thesis, Wageningen Unoiversity. (Cited on pages 7, 8, 9, and 12.)

Sylwan, P. (2011), "The land and the forest - an essay on changes in farming and forestry", in Antonson, A. and Jansson, U., eds., Agriculture and forestry in Sweden since 1900: Geographical and historical studies, Skogs- och landbrukhistoriska meddelanden, 54, pp. 9-24, Stockholm (The Royal Swedish Academy of Agriculture and Forestry). (Cited on pages 6 and 13.)

Thomas, J. (1993), "The Hermeneutics of Megalithic Space", in Tilley, C., ed., Interpretative Archaeology, Explorations in Anthropology, pp. 73-98, Oxford; Providence (Berg). (Cited on page 10.)

Tilley, C. (1994), A Phenomenology of Landscape: Places, Paths, and Monuments, Oxford; Providence (Berg). (Cited on pages 5, 10, and 12.)

Tilley, C. (2004), The Materiality of Stone: Explorations in Landscape Phenomenology, Oxford; Providence (Berg). [Google Books]. (Cited on page 12.)

Torop, P. (2012), "Ajaloo keeled", in Harro-Loit, H. and Tasa, M., eds., Õpetaja kui kultuurimälu vahendaja. Kultuurilise identiteedi mõtestamise ja tõlgendamise võimalusi, pp. 21-43, Tartu (Tartu University Press). (Cited on page 10.)

Urtāns, J. (1998), "Where was the Metsepole castle situated?", in Blomkvist, N., ed., Culture clash or compromise? The Europeanisation of the Baltic Sea area 1100-1400 AD, Acta Visbyensia, XI, pp. 124-130, Visby (Gotland Centre for Baltic Studies). (Cited on page 8.) 
van Beek, R. (2011), "Diversity Rules: On Late Prehistoric Settlement of the Eastern Netherlands and the Need for Regionally Specific Models", Proceedings of the Prehistoric Society, 77: 25-47, [DOI]. (Cited on pages 7 and 8.)

van Beek, R. and Louwen, A. (2012), "Urnfields on the move: Testing burial site-settlement relations in the eastern Netherlands (c. 1100-500 BC)", Archäologisches Korrespondenzblatt, 42(1): 41-60. Online version (accessed 25 February 2014): http://hdl.handle.net/1887/20159. (Cited on page 7.)

Vedru, G. (2002), "Maastik, aeg ja inimesed", in Lang, V., ed., Keskus - tagamaa - ääreala: Uurimusi asustushierarhia ja võimukeskuste kujunemisest Eestis, Muinasaja Teadus / Research into Ancient Times, 11, pp. 101-118, Tallinn; Tartu (Teaduste Akadeemia Kirjastus). (Cited on page 6.)

Vedru, G. (2009), "Layers of landscape, layers of site", Estonian Journal of Archaeology, 13(1): 21-35, [DOI]. (Cited on pages 9 and 11.)

Vedru, G. (2010), Põhja-Eesti arheoloogilised maastikud [Archaeological landscapes of North-Estonia], Ph.D. thesis, Tartu University, Tartu. Online version (accessed 13 February 2014): http://hdl.handle.net/10062/16297. (Cited on page 12.)

Vedru, G. (2013), "Searching for heights in North Estonia", in Johanson, K. and Tõrv, M., eds., Man, His Time, Artefacts, and Places: Collection of articles dedicated to Richard Indreko, Muinasaja Teadus / Research into Ancient Times, 19, pp. 547-751,, Tartu (Tartu University Press). (Cited on page 12.)

Vervloet, J.A.J., ed. (1984), Inleiding tot de historische geografie van de Nederlandse cultuurlandschappen, Reeks Landschapsstudies, 4, Wageningen (Pudoc). (Cited on page 11.)

Viik, T. (2009), "Fenomenoloogia: sissejuhatus [Phenomenology: An Introduction]", in Annus, E., ed., 20. sajandi môttevoolud, pp. 215-228, Tartu (Tartu University Press). (Cited on page 10.)

Widgren, M. (2006), "Time and Space in European Landscape Research", Presentation at the 22nd session of PECSRL, Berlin, conference paper. (Cited on page 6.)

Widgren, M. (2012), "Landscape research in a world of domesticated landscapes: the role of values, theory and concepts", Quaternary International, 251: 117-124, [DOI]. (Cited on page 6.)

Wylie, J. (2007), Landscape, Key Ideas in Geography, London; New York (Routledge). (Cited on page 12.)

Wylie, J. (2009), "Landscape, absence, and the geographies of love", Transactions of the Institute of British Geographers, 34(3): 257-289, [DOI]. (Cited on page 12.)

Zariņa, A. (2013), "Path dependence and landscape: initial conditions, contingency and sequences of events in Latgale, Latvia", Geografiska Annaler: Series B, Human Geography, 95(4): 355-373, [DOI]. (Cited on pages 6 and 9.) 